University of Nebraska - Lincoln

DigitalCommons@University of Nebraska - Lincoln

\title{
Interannual variability in carbon dioxide fluxes and flux-climate relationships on grazed and ungrazed northern mixed-grass prairie
}

\author{
H. Wayne Polley \\ USDA-ARS Grassland, Soil and Water Research Laboratory, wayne.polley@ars.usda.gov \\ Albert B. Frank \\ Northern Great Plains Research Laboratory \\ Joaquin Sanabria \\ Texas Agricultural Experiment Station \\ Rebecca L. Phillips \\ Northern Great Plains Research Laboratory
}

Follow this and additional works at: https://digitalcommons.unl.edu/usdaarsfacpub

Part of the Agricultural Science Commons

Polley, H. Wayne; Frank, Albert B.; Sanabria, Joaquin; and Phillips, Rebecca L., "Interannual variability in carbon dioxide fluxes and flux-climate relationships on grazed and ungrazed northern mixed-grass prairie" (2008). Publications from USDA-ARS / UNL Faculty. 439.

https://digitalcommons.unl.edu/usdaarsfacpub/439

This Article is brought to you for free and open access by the U.S. Department of Agriculture: Agricultural Research Service, Lincoln, Nebraska at DigitalCommons@University of Nebraska - Lincoln. It has been accepted for inclusion in Publications from USDA-ARS / UNL Faculty by an authorized administrator of DigitalCommons@University of Nebraska - Lincoln. 


\title{
Interannual variability in carbon dioxide fluxes and flux-climate relationships on grazed and ungrazed northern mixed-grass prairie
}

\author{
H. WAYNE POLLEY*, ALBERT B. FRANK†, JOAQUIN SANABRIA $\ddagger$ and \\ REBECCA L. PHILLIPS † \\ ${ }^{*}$ Grassland, Soil and Water Research Laboratory, US Department of Agriculture, Agricultural Research Service, Temple, TX $76502-$ \\ 9622, USA, †Northern Great Plains Research Laboratory, US Department of Agriculture, Agricultural Research Service, Mandan, \\ ND 58554, USA, $\ddagger$ Blackland Research and Extension Center, Texas Agricultural Experiment Station, Temple, TX 76502-9622, USA
}

\begin{abstract}
The annual carbon (C) budget of grasslands is highly dynamic, dependent on grazing history and on effects of interannual variability (IAV) in climate on carbon dioxide $\left(\mathrm{CO}_{2}\right)$ fluxes. Variability in climatic drivers may directly affect fluxes, but also may indirectly affect fluxes by altering the response of the biota to the environment, an effect termed 'functional change'. We measured net ecosystem exchange of $\mathrm{CO}_{2}(\mathrm{NEE})$ and its diurnal components, daytime ecosystem $\mathrm{CO}_{2}$ exchange $\left(P_{\mathrm{D}}\right)$ and night-time respiration $\left(R_{\mathrm{E}}\right)$, on grazed and ungrazed mixed-grass prairie in North Dakota, USA, for five growing seasons. Our primary objective was to determine how climatic anomalies influence variability in $\mathrm{CO}_{2}$ exchange. We used regression analysis to distinguish direct effects of IAV in climate on fluxes from functional change. Functional change was quantified as the improvement in regression on fitting a model in which slopes of flux-climate relationships vary among years rather than remain invariant. Functional change and direct effects of climatic variation together explained about $20 \%$ of variance in weekly means of NEE, $P_{\mathrm{D}}$, and $R_{\mathrm{E}}$. Functional change accounted for more than twice the variance in fluxes of direct effects of climatic variability. Grazing did not consistently influence the contribution of functional change to flux variability, but altered which environmental variable best explained year-to-year differences in flux-climate slopes, reduced IAV in seasonal means of fluxes, lessened the strength of flux-climate correlations, and increased NEE by reducing $R_{\mathrm{E}}$ relatively more than $P_{\mathrm{D}}$. Most of these trends are consistent with the interpretation that grazing reduced the influence of plants on ecosystem fluxes. Because relationships between weekly values of fluxes and climatic regulators changed annually, year-to-year differences in the $C$ balance of these ecosystems cannot be predicted from knowledge of IAV in climate alone.
\end{abstract}

Keywords: climatic variability, daytime ecosystem $\mathrm{CO}_{2}$ exchange, functional change, net ecosystem exchange of $\mathrm{CO}_{2}$, night-time respiration

Received 16 August 2007 and accepted 28 December 2007

\section{Introduction}

In the absence of disturbances that remove carbon (C), the $\mathrm{C}$ budget of terrestrial ecosystems is determined largely by the balance between net uptake of $\mathrm{CO}_{2}$ via

Correspondence: H. Wayne Polley, tel. +254 770 6629, fax +254 770 6561, e-mail: wayne.polley@ars.usda.gov photosynthesis and $\mathrm{CO}_{2}$ loss to respiration. Even at the annual time scale, this balance may be highly dynamic. Multi-year studies in numerous ecosystems have shown that year-to-year variation in NEE and its component fluxes may be large (Barford et al., 2001; Sims \& Bradford, 2001; Frank, 2002). Interannual variability (IAV) in $\mathrm{CO}_{2}$ fluxes may be especially great for grassland ecosystems, which exhibit the largest variability in aboveground net primary productivity of biomes in North America (Knapp \& Smith, 2001). Long-term flux 
measurements for grassland ecosystems are relatively few, but available results indicate that grasslands may regularly shift between functioning as a $\mathrm{C}$ sink and a C source (Flanagan et al., 2002; Frank, 2002; Owensby et al., 2006). Grazed northern mixed-grass prairie functioned as a small $\mathrm{C}$ sink for 2 years, but as a $\mathrm{C}$ source during the third year, for example (Frank, 2002). Ungrazed grassland in Alberta, Canada exhibited similar variability in net ecosystem exchange of $\mathrm{CO}_{2}$ (NEE), functioning as a $\mathrm{C}$ sink during 2 of 3 years (Flanagan et al., 2002).

Year-to-year change in ecosystem $C$ budgets usually is attributed to climatic variability (Tian et al., 1998; Barford et al., 2001; Flanagan et al., 2002; Xu \& Baldocchi, 2004), which may both directly and indirectly affect $\mathrm{CO}_{2}$ fluxes. Fluxes may respond directly to variation in climatic drivers. Alternatively, climatic anomalies may indirectly affect fluxes by altering the response of the biota to environmental drivers. Hui et al. (2003) used regression analyses to show that contributions of direct and indirect effects of climatic variability to IAV in NEE were similar for loblolly pine forest (Pinus taeda L.). Richardson et al. (2007) attributed slightly more of variance in NEE for spruce forest to year-to-year change in biotic responses to environmental forcing than to direct effects of climatic change.

At annual and longer time scales, NEE also depends on disturbance history (Barford et al., 2001; Saleska et al., 2003). Among the numerous disturbances to which grassland ecosystems are exposed, grazing is perhaps the most ubiquitous. Virtually all natural grasslands are grazed by wild or domesticated ungulates for some portion of the year. By removing plant biomass, grazers often modify canopy structure and the energy balance of grasslands, with resulting feedbacks on soil temperature (ST) and soil water balance (Zhou et al., 2007) and, ultimately, on net $C$ uptake (Owensby et al., 2006; Soussana et al., 2007). Grazing need not reduce canopy photosynthesis or grassland NEE as greatly as biomass, however, for leaves that regrow following defoliation often are more physiologically active than the older leaves that contribute much of leaf area on ungrazed grassland (Owensby et al., 2006). In order to predict ecosystem $\mathrm{C}$ balance, we clearly must better understand how disturbances like grazing affect IAV in $\mathrm{CO}_{2}$ exchange.

Following Hui et al. (2003), we propose that IAV in $\mathrm{CO}_{2}$ fluxes is caused mainly by climatic variability through direct effects on the physiological processes of photosynthesis and respiration and via indirect effects on biological and ecological processes that regulate carbon uptake and loss. Hui et al. (2003) used the term 'functional change' to describe indirect effects of climatic variability and developed a regression procedure to distinguish the contributions of functional change and of direct effects of climatic anomalies to IAV in $\mathrm{CO}_{2}$ fluxes.

We used the homogeneity-of-slopes (HOS) regression procedure developed by Hui et al. (2003) to distinguish IAV from seasonal variability in $\mathrm{CO}_{2}$ fluxes on currently grazed and ungrazed northern mixed-grass prairie in North Dakota, USA, and to partition the contributions of functional change and of direct effects of climatic variability to IAV in fluxes. Functional change results when weather and climate anomalies alter biological and ecological processes that regulate photosynthesis and respiration. Many of these processes, including canopy development, $\mathrm{N}$ mineralization rates, and soil water dynamics, also may be affected by cattle grazing (Biondini et al., 1998), implying that grazing may change both IAV in fluxes and the contribution of functional change to flux variability. The greater is the plant biomass, the greater should be the absolute response of $\mathrm{CO}_{2}$ fluxes to seasonal changes in light, temperature, and other climatic variables. By reducing plant biomass, grazers may reduce the response of $\mathrm{CO}_{2}$ fluxes to climatic variation. Plant photosynthesis likely is affected most directly by any reduction in biomass, but grassland respiration also depends on the availability of recently fixed carbon (Craine et al., 1999; Polley et al., 2006). We predicted, therefore, that grazing would reduce IAV in NEE and its component fluxes, daytime ecosystem $\mathrm{CO}_{2}$ exchange $\left(P_{\mathrm{D}}\right)$ and night-time respiration $\left(R_{\mathrm{E}}\right)$, and reduce the contribution of functional change to IAV in $\mathrm{CO}_{2}$ fluxes on northern mixed-grass prairie.

\section{Materials and methods}

\section{Site description}

Fluxes were measured on grazed and ungrazed mixedgrass prairie located at the Northern Great Plains Research Laboratory in Mandan, North Dakota, USA $\left(46^{\prime} \mathrm{E} 46^{\prime} \mathrm{N}, 100^{\prime} \mathrm{E} 55^{\prime} \mathrm{W}\right)$. Vegetation at both sites is dominated by Bouteloua gracilis (H. B. K.) Lag. ex Griffiths [blue grama], Stipa comata Trin. and Rupr. [needle-andthread], Schizachyrium scoparium (Michx.) Nash [little bluestem], Bouteloua curtipendula (Michx. Torr.) [sideoats grama], and Poa pratensis L. [Kentucky bluegrass]. Predominant soils are Temvik-Wilton silt loams (FAO: Calcic Siltic Chernozems; USDA: fine-silty, mixed, superactive, frigid Typic and Pachic Haplustolls). Annual precipitation averages $412 \mathrm{~mm}$ (1913-2006), with $\sim 65 \%$ falling during the growing season (AprilSeptember). Neither fertilizers nor herbicides have been applied to the prairies. The currently ungrazed prairie was last grazed in 1992. The currently grazed prairie 
has been grazed at 2.6 ha per steer from mid-May to October each year since 1916 (Frank \& Dugas, 2001; Frank, 2002), a grazing intensity considered to be light to moderate.

\section{$\mathrm{CO}_{2}$ fluxes and climatic variables}

We measured $\mathrm{CO}_{2}$ fluxes on each prairie every $20 \mathrm{~min}$ from April 16 through October 28 of 1997-2001 using Bowen ratio/energy balance (BREB) instrumentation (Model $023 / \mathrm{CO}_{2}$ Bowen ratio system, Campbell Scientific Inc., Logan, UT, USA). Flux rates were calculated using methods described by Dugas (1993) and Dugas et al. (1999). Bowen ratios were calculated using air temperature and water vapor gradients measured every $2 \mathrm{~s}$ at 1 and $2 \mathrm{~m}$ above the plant canopy. Gradients in water vapor and $\mathrm{CO}_{2}$ were measured with Model 6262 infrared gas analyzers (Li-Cor Inc., Lincoln, NE, USA) that were calibrated weekly. Sensible heat flux was calculated using the Bowen ratio, average net radiation $(\mathrm{Rn})$ measured with Model $\mathrm{Q}^{*} 7.0$ and 7.1 net radiometers (REBS, Seattle, WA, USA), and soil heat flux measured using two Model HFT soil heat flux plates (REBS, Seattle, WA, USA). The turbulent diffusivity, assumed equal for heat, water vapor, and $\mathrm{CO}_{2}$, was calculated using the temperature gradient, sensible heat flux, and air density. Carbon dioxide fluxes $\left(\mathrm{mg} \mathrm{m}^{-2} \mathrm{~s}^{-1}\right)$ were derived by multiplying turbulent diffusivity by the change in the density of $\mathrm{CO}_{2}$ measured between 1 and $2 \mathrm{~m}$ above the canopy and correcting for differences in water vapor density (Webb et al., 1980). Latent heat was determined as the energy remaining after subtracting soil heat flux and sensible heat flux from net radiation. Evapotranspiration (ET) was calculated by dividing the latent heat of evaporation by the latent heat of vaporization. Flux toward the surface was considered to be negative in sign. When turbulent diffusivity estimated by the BREB approach failed, as evidenced by differences in signs of the sensible/latent heat flux calculations and the temperature/water vapor gradient, we calculated turbulent diffusivity using wind speed (WS), atmospheric stability, and canopy height (Dugas et al., 1999). This alternative method of estimating diffusivity was used in about $10 \%$ of calculations, which were observed mostly at night. Aerodynamic methods for measuring diffusivity may fail during periods of stable atmospheric conditions, which often occur at night. Frank et al. (2000), however, showed that $\mathrm{CO}_{2}$ fluxes measured at night on grasslands using the BREB method were only slightly smaller than the sum of estimated night-time plant and soil respiratory losses. Fluxes calculated using the BREB method also have been shown to be similar to those estimated from biomass production (Dugas et al.,
1999) and measured using canopy chambers (Angell et al., 2001) and to daytime and night fluxes measured using the eddy covariance technique (Dugas et al., 2001). Days for which data were missing were few (0-10 days per growing season). We did not attempt to gap-fill missing data.

Climatic variables were measured every $2 \mathrm{~s}$ and were averaged every $20 \mathrm{~min}$. ST was calculated using the average of two Type $\mathrm{E}$ thermocouple probes located at 2 and $6 \mathrm{~cm}$ depths. WS was measured using Model 03001 R.M. Young Wind Sentry Set (R.M. Young Co., Traverse City, MI, USA). The relative humidity (RH), vapor pressure (e), and temperature of air (AT) were measured with Model HMP35C probe (Vaisala Inc., Woburn, MA, USA). Precipitation was measured using Model TR-525USW tipping bucket rain gauge (Texas Electronics Inc., Dallas, TX, USA). Following Stephenson (1990), we define the parameter 'deficit' as evaporative demand not met by available water. A value of deficit for each day was calculated as the difference between daily values of potential evapotranspiration (PET) and actual evapotranspiration (AET). Daily values of PET were calculated with the Food and Agriculture Organization of the United Nations (FAO) Penman-Monteith equation using measurements of Rn, WS, AT, and e. Daily values of AET were calculated by summing $20 \mathrm{~min}$ averages for ET.

Leaf area was measured at four positions surrounding Bowen ratio equipment on each prairie at approximately 2-week intervals during growing seasons in 1997-2000. On each sampling date, one quadrat $\left(0.25 \mathrm{~m}^{2}\right)$ was randomly placed within each of the four permanently located plots (each $30 \mathrm{~m} \times 30 \mathrm{~m}$ ) in each prairie. Vegetation in each quadrat was clipped to ground level, and the surface area of green tissues (leaf area) was measured with a photoelectric meter.

Daily values of NEE were calculated from measurements every $20 \mathrm{~min}$. The mean rate of ecosystem respiration at night $\left(R_{\mathrm{E}}\right)$ was calculated for each day using measurements between 20:20 and 04:20 hours. The average rate of daytime ecosystem $\mathrm{CO}_{2}$ exchange $\left(P_{\mathrm{D}}\right)$ was calculated for each day using measurements from 08:20 to 18:20 hours. Climatic variables (ST, WS, RH, Rn, and deficit) also were averaged over each of these daylight and night-time periods. By excluding data collected during transitions between daylight and darkness each day, we sought to eliminate possible confounding effects of transitions on estimates of $P_{\mathrm{D}}$ and $R_{\mathrm{E}}$. Data for days on which equipment malfunctioned were excluded.

In order to reduce fluctuations inherent in daily values, we calculated weekly means of $\mathrm{CO}_{2}$ fluxes and climatic variables. For each week during each growing season, we also calculated the weekly sum of precipita- 
tion (ppt1) and the unweighted mean of the weekly sums of precipitation for the current week and the previous 1-4 weeks (simple moving average of the weekly sum of precipitation for $2-5$ weeks; denoted as ppt2-ppt5).

\section{Homogeneity-of-slopes (HOS) model}

We used the approach developed by Hui et al. (2003) to statistically partition variation in observed values of $\mathrm{CO}_{2}$ fluxes (NEE, $P_{\mathrm{D}}, R_{\mathrm{E}}$ ) into seasonal and inter-annual components. We first tested for linearity of flux-climate relationships using simple linear regression analysis with data from all the 5 years combined. Among all the pairwise relationships between NEE, $P_{\mathrm{D}}$, or $R_{\mathrm{E}}$ and climatic variables, only the $R_{\mathrm{E}}-\mathrm{ST}$ relationship for ungrazed prairie was slightly better described by a nonlinear than linear function. For each prairie, we used stepwise multiple linear regression (forward selection of variables) analysis to determine relationships between weekly means of $\mathrm{CO}_{2}$ fluxes and the weekly averages of climatic variables that were significantly correlated with fluxes in simple regression (singleslopes model). When climatic predictors of fluxes covary through time (are collinear), each predictor variable has both a unique and shared contribution to changes in fluxes. The partial regression coefficients calculated in multiple regression models account for only the unique contributions of predictors, which are reflected in the Type III sum of squares (SS) for each variable.

Climatic variables that were retained in multiple regression models with fluxes when data from all years were considered then were entered into a HOS analysis (separate-slopes model). An indirect effect of climatic variability on IAV in $\mathrm{CO}_{2}$ flux or functional change was detected when the slope of one or more of the fluxclimate relationships differed significantly among the years. Finally, we statistically partitioned total variance in fluxes among functional change, the direct effects of inter-annual climatic variability, the direct effects of seasonal climatic variability, and random error by partitioning the total sum of squares $\left(\mathrm{SS}_{\mathrm{t}}\right)$ among these components.

The SS for functional change was calculated by summing across years the squared difference between $\mathrm{CO}_{2}$ fluxes estimated using a separate-slopes regression model and fluxes calculated with a single-slope multiple regression model. Inter-annual variability in climate contributes directly to IAV in NEE, $P_{\mathrm{D}}$, and $R_{\mathrm{E}}$. The SS for direct effects of inter-annual climatic variability was calculated by summing across years the squared difference between $\mathrm{CO}_{2}$ flux estimated for each week with a single-slope regression model and the average of the modeled estimates of flux for the given week. Differ- ences between means of estimated NEE, $P_{\mathrm{D}}$, or $R_{\mathrm{E}}$ across all years for a given week and the mean of flux estimates for all weeks result from week-to-week changes in climatic variables. The squared sum of these differences equals the direct effect of seasonal variability in climate on fluxes. The SS attributable to random error was calculated by summing across years the squared difference between flux measured on a given week and flux estimated for that week with the separate-slopes regression model.

\section{Results}

\section{Variability in fluxes, climatic variables, and LAI}

Carbon fluxes varied seasonally and inter-annually (Figs 1-3). NEE, for example, increased (became more negative) from the winter low to a maximum in summer then declined in late summer and autumn during
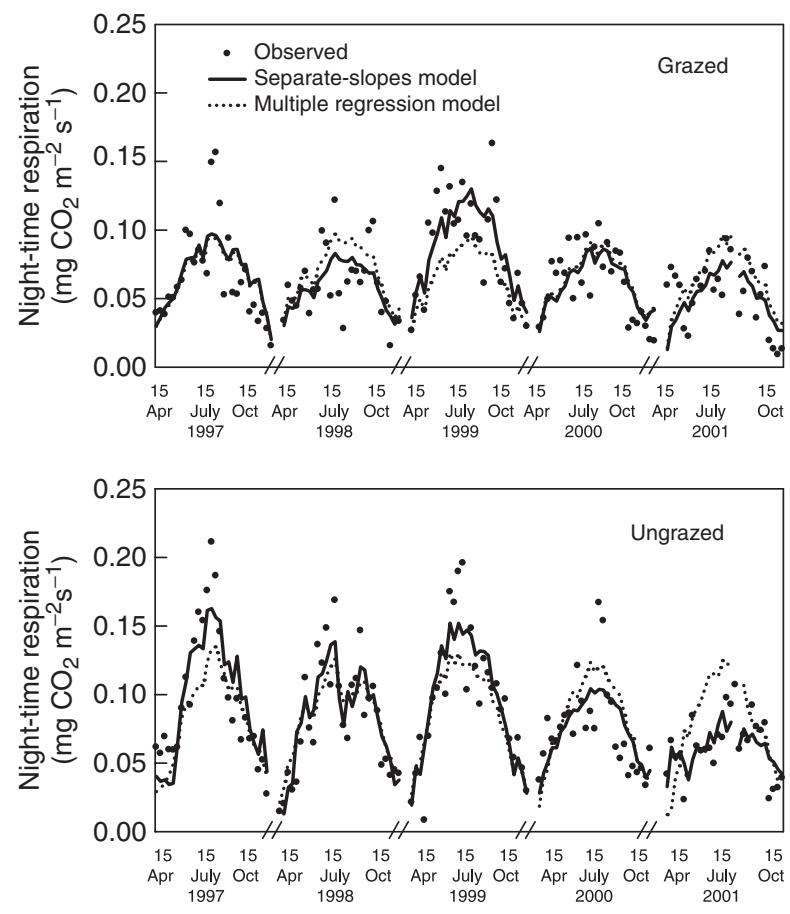

Fig. 1 Weekly means of the rate of night-time respiration $\left(R_{\mathrm{E}}\right)$ for grazed and ungrazed mixed-grass prairie during five growing seasons. Dashed lines indicate flux estimates derived from a multiple regression model fit to weekly values of $R_{\mathrm{E}}$ from all years combined $\left(r^{2}=0.40\right.$ and 0.56 for grazed and ungrazed prairie, respectively). The solid line indicates flux estimates derived from a separate-slopes regression model in which slopes of significant relationships between $R_{\mathrm{E}}$ and climatic variables were allowed to vary among the years rather than remain invariant $\left(r^{2}=0.58\right.$ and 0.75 for grazed and ungrazed prairie, respectively). 

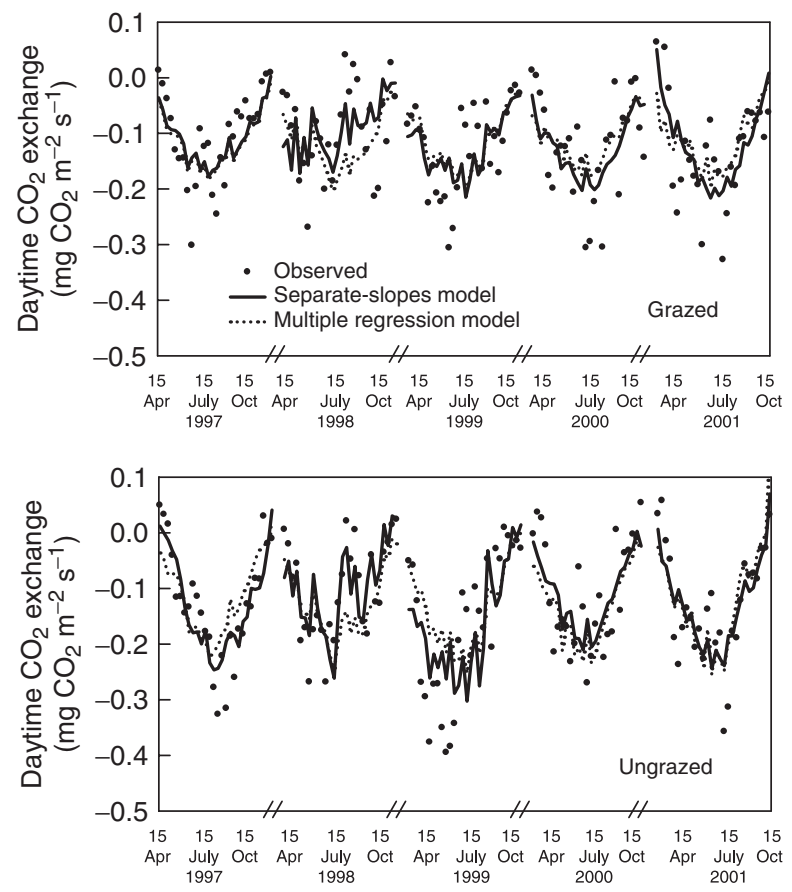

Fig. 2 Weekly means of the rate of daytime ecosystem $\mathrm{CO}_{2}$ exchange $\left(P_{\mathrm{D}}\right)$ for grazed and ungrazed mixed-grass prairie during five growing seasons. Dashed lines indicate flux estimates derived from a multiple regression model fit to weekly values of $P_{\mathrm{D}}$ from all years combined $\left(r^{2}=0.31\right.$ and 0.47 for grazed and ungrazed prairie, respectively). The solid line indicates flux estimates derived from a separate-slopes regression model in which slopes of significant relationships between $P_{\mathrm{D}}$ and climatic variables were allowed to vary among the years rather than remain invariant $\left(r^{2}=0.41\right.$ and 0.60 for grazed and ungrazed prairie, respectively).

most growing seasons (Fig. 3). But, the timing of peak NEE differed among the years. In three of the 5 years, NEE on ungrazed prairie was maximal during June and July. However, the NEE peaked at the end of May 1998 and during the period from late April through June in 1999. Growing season means of fluxes also varied substantially. The mean of NEE varied by greater than a factor of 2 among the 5 years of measurements for grazed prairie and by greater than a factor of 3 for ungrazed prairie (Table 1). Variability was smaller in both $P_{\mathrm{D}}$ and $R_{\mathrm{E}}$ than in NEE, but IAV in the seasonal mean of $P_{\mathrm{D}}$ also was larger on ungrazed than grazed prairie.

Grazing reduced mean rates of $P_{\mathrm{D}}$ in four of the 5 years and rates of $R_{\mathrm{E}}$ in all years, but increased NEE each year except 1999 (Table 1). Grazing apparently stimulated NEE by reducing $R_{\mathrm{E}}$ more than $P_{\mathrm{D}}$. During the 5 years of flux measurements, the seasonal mean of $R_{\mathrm{E}}$ was smaller by an average of $20 \%$ on the grazed than ungrazed site. $P_{\mathrm{D}}$ was $<10 \%$ smaller, on average, on grazed than ungrazed prairie.
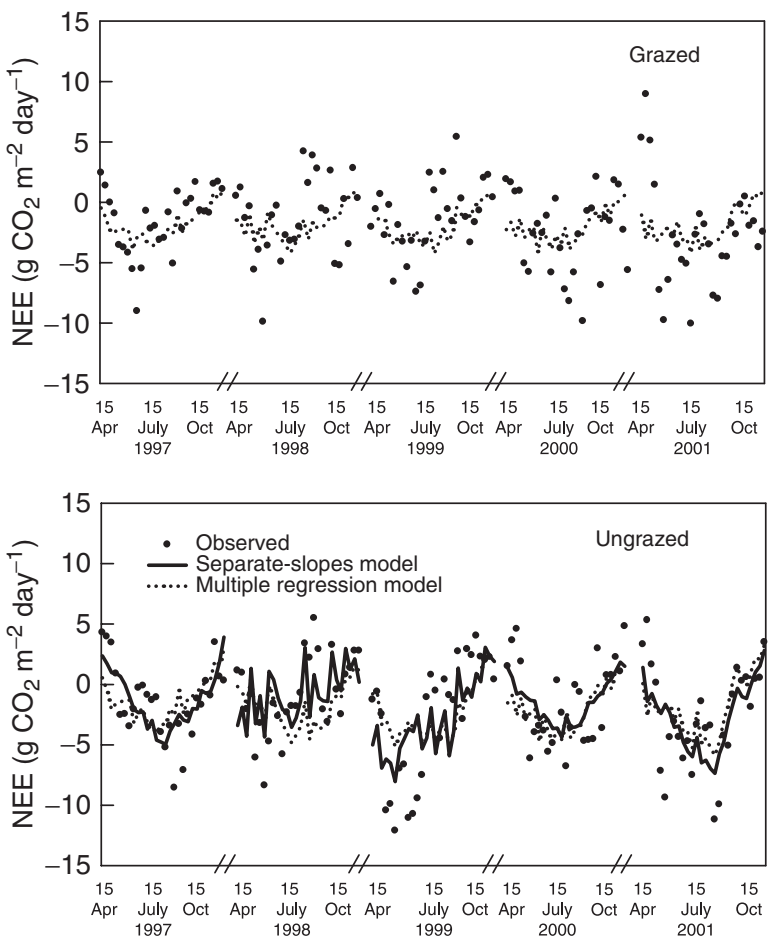

Fig. 3 Weekly means of net ecosystem exchange of $\mathrm{CO}_{2}$ (NEE) for grazed and ungrazed mixed-grass prairie during five growing seasons. Dashed lines indicate flux estimates derived from a multiple regression model fit to weekly values of NEE from all years combined $\left(r^{2}=0.16\right.$ and 0.29 for grazed and ungrazed prairie, respectively). The solid line indicates flux estimates derived from a separate-slopes regression model in which slopes of significant relationships between NEE and climatic variables were allowed to vary among the years rather than remain invariant $\left(r^{2}=0.44\right)$.

Table 1 Mean values of daily NEE and of daytime $\left(P_{\mathrm{D}}\right)$ and night-time $\left(R_{\mathrm{E}}\right) \mathrm{CO}_{2}$ exchange rates measured on grazed and ungrazed northern mixed-grass prairie

$\begin{array}{lll}\mathrm{NEE} & P_{\mathrm{D}} & R_{\mathrm{E}} \\ \left(\mathrm{gCO}_{2} \mathrm{~m}^{-2} \mathrm{day}^{-1}\right) & \left(\mathrm{mgCO} \mathrm{m}^{-2} \mathrm{~s}^{-1}\right) & \left(\mathrm{mgCO}_{2} \mathrm{~m}^{-2} \mathrm{~s}^{-1}\right)\end{array}$

Year Grazed Ungrazed Grazed Ungrazed Grazed Ungrazed

\begin{tabular}{lllllll}
\hline 1997 & -1.55 & -1.40 & -0.105 & -0.126 & 0.066 & 0.094 \\
$1998-1.33$ & -0.83 & -0.095 & -0.102 & 0.060 & 0.084 \\
$1999-1.33$ & -2.87 & -0.126 & -0.166 & 0.088 & 0.098 \\
2000 & -2.51 & -1.37 & -0.125 & -0.109 & 0.061 & 0.076 \\
2001 & -2.74 & -2.67 & -0.122 & -0.127 & 0.053 & 0.062 \\
\hline
\end{tabular}

Values were calculated by averaging weekly means of daily values during each growing season (days 106-301; 28 weeks).

Peak values of LAI, the day of the year on which LAI peaked each season, and annual means of climatic variables, including $\mathrm{AT}, \mathrm{ST}$, and precipitation, differed among years and between prairies (Table 2). Surpris- 
Table 2 Precipitation measured before and during each growing season and mean values of air and soil temperatures (AT and ST, respectively) plus peak values of LAI and the day of the year on which LAI peaked each season for grazed and ungrazed northern mixed-grass prairie

\begin{tabular}{|c|c|c|c|c|c|c|c|c|c|c|c|c|}
\hline \multirow[b]{2}{*}{ Year } & \multicolumn{2}{|c|}{$\begin{array}{l}\text { Precipitation } \\
(\mathrm{mm})\end{array}$} & \multicolumn{2}{|c|}{ AT $\left({ }^{\circ} \mathrm{C}\right.$; daylight $)$} & \multicolumn{2}{|c|}{ ST $\left({ }^{\circ} \mathrm{C}\right.$; daylight $)$} & \multicolumn{2}{|c|}{ ST $\left({ }^{\circ} \mathrm{C}\right.$, night $)$} & \multicolumn{2}{|c|}{ LAI (peak value) } & \multicolumn{2}{|c|}{$\begin{array}{l}\text { LAI (day of peak } \\
\text { value) }\end{array}$} \\
\hline & $\begin{array}{l}\text { Before } \\
\text { season }\end{array}$ & $\begin{array}{l}\text { Growing } \\
\text { season }\end{array}$ & Grazed & Ungrazed & Grazed & Ungrazed & Grazed & Ungrazed & Grazed & Ungrazed & Grazed & Ungrazed \\
\hline 1997 & 143.6 & 219.8 & 19.5 & 19.8 & 16.1 & 15.0 & 14.5 & 14.5 & 0.53 & 0.40 & 209 & 231 \\
\hline 1998 & 58.3 & 381.0 & 19.7 & 20.0 & 16.9 & 16.0 & 15.4 & 15.5 & 0.50 & 0.45 & 189 & 174 \\
\hline 1999 & 87.7 & 527.9 & 17.7 & 18.3 & 16.0 & 14.6 & 14.5 & 14.3 & 1.00 & 0.64 & 174 & 174 \\
\hline 2000 & 99.5 & 348.0 & 18.8 & 19.4 & 15.3 & 14.9 & 14.1 & 14.6 & 0.74 & 0.58 & 189 & 209 \\
\hline 2001 & 112.0 & 402.2 & 19.2 & 19.4 & 15.5 & 14.8 & 13.9 & 13.9 & - & - & - & - \\
\hline
\end{tabular}

Temperatures were calculated using weekly means of daily values each growing season (days 106-301; 28 weeks). Precipitation was summed from the end of the previous growing season to the beginning of the current season (before season; 24 weeks) and for each growing season (28 weeks).

ingly, LAI was greater each year and varied more among the 4 years of measurements on grazed than ungrazed prairies. Daytime means of AT were slightly smaller for the grazed than ungrazed prairie, but ST during daylight was greater each year at the grazed site. Mean values of ST at night were similar between prairies. Precipitation varied by greater than a factor of 2 among years.

\section{Night-time respiration - seasonal and inter-annual variability}

Simple linear regression was used to determine relationships between weekly means of $R_{\mathrm{E}}$ and means of both climatic variables and $P_{\mathrm{D}}$ measured during the daylight period preceding respiration measurements. For both grazed and ungrazed prairie, data from all 5 years were included in each regression. $R_{\mathrm{E}}$ on ungrazed prairie correlated most highly with ST $(r=0.71)$, but also was significantly correlated with $\mathrm{Rn}(r=0.54), P_{\mathrm{D}}$ $(r=-0.55)$, and deficit $(r=-0.51) . R_{\mathrm{E}}$ on the grazed prairie also correlated highly with ST $(r=0.63)$, but regressions with $\mathrm{Rn}(r=0.51), P_{\mathrm{D}}(r=-0.37)$, and ppt5 $(r=0.50)$ were significant. Among these relationships, only that between $R_{\mathrm{E}}$ and ST for ungrazed prairie deviated from linearity. An exponential equation fit the $R_{\mathrm{E}}$-ST relationship only slightly better than did a linear equation $\left(r^{2}\right.$ increased from 0.51 to 0.53$)$, however, so the linear relationship was considered adequate.

Stepwise multiple regression was used to relate weekly means of $R_{\mathrm{E}}$ on grazed and ungrazed prairie to variables that were significantly correlated with $R_{\mathrm{E}}$ in simple regression (Fig. 1). The final multiple regression model for the grazed prairie included ST only $\left[R_{\mathrm{E}}\right.$ $\left(\mathrm{mg} \mathrm{m}^{-2} \mathrm{~s}^{-1}\right)=0.008+0.004 \times \mathrm{ST} ; \quad P<0.0001, r^{2}=0.40$, $n=139]$. The multiple regression model for the ungrazed prairie included three variables, ST, $P_{\mathrm{D}}$, and deficit $\left[R_{\mathrm{E}} \quad\left(\mathrm{mg} \mathrm{m}^{-2} \mathrm{~s}^{-1}\right)=0.018+0.004 \times \mathrm{ST}-0.060 \times\right.$ $P_{\mathrm{D}}-0.008 \times$ deficit; $\left.P<0.0001, r^{2}=0.56, n=137\right)$.

For each prairie, slopes of regression relationships between $R_{\mathrm{E}}$ and each variable retained in the multiple regression model varied significantly among years $(P<0.05)$, meaning that IAV in $R_{\mathrm{E}}$ on both grazed and ungrazed prairies resulted partly from functional change. Indeed, functional change explained 17.4\% and $18.8 \%$ of variance in $R_{\mathrm{E}}$ for grazed and ungrazed prairies, respectively (Table 3 ), and explained more than four times the variance in $R_{\mathrm{E}}$ of direct effects of interannual variation in climate $(2.8 \%$ and $4.3 \%$ for grazed and ungrazed prairies, respectively). Permitting significant flux-climate relationships to vary among years rather than remain invariant, significantly improved regression estimates of $R_{\mathrm{E}}$, particularly during the 1999 season on grazed prairie and 2001 season on ungrazed prairie (Fig. 1). Seasonal climatic variation accounted for the bulk of variance explained by the separate-slopes model for each prairie (Table 3). The variance in $R_{\mathrm{E}}$ accounted for by regression models was smaller for grazed than ungrazed prairie.

For the grazed prairie, functional change resulted because slopes of relationships between weekly means of $R_{\mathrm{E}}$ and ST varied among years (Table 4). For the ungrazed prairie, functional change resulted because slopes of relationships between $R_{\mathrm{E}}$ and three variables, $\mathrm{ST}, P_{\mathrm{D}}$, and deficit, varied among years. Slopes were not correlated with seasonal means of climatic variables or with precipitation measured before or during the growing season for either prairie, but slopes of $R_{\mathrm{E}}-\mathrm{ST}$ regressions for grazed prairie were positively and linearly correlated with the mean of ST from the previous 
Table 3 Results from HOS models in which variation in observed values of NEE (net ecosystem exchange of $\mathrm{CO}_{2}$; $\mathrm{g} \mathrm{m}^{-2}$ day $^{-1}$ ) and of rates of $P_{\mathrm{D}}$ (daytime ecosystem exchange of $\mathrm{CO}_{2} ; \mathrm{mg} \mathrm{m}^{-2} \mathrm{~s}^{-1}$ ) and $R_{\mathrm{E}}$ (night-time ecosystem respiration; $\mathrm{mg} \mathrm{m}^{-2} \mathrm{~s}^{-1}$ ) on grazed and ungrazed mixed-grass prairie was partitioned into four components, the direct effects of interannual climatic variability (inter-annual), the directs effects of seasonal climatic variability (seasonal), functional change, and random error

\begin{tabular}{|c|c|c|c|c|}
\hline \multirow[b]{2}{*}{ Source } & \multicolumn{2}{|l|}{ Grazed } & \multicolumn{2}{|c|}{ Ungrazed } \\
\hline & SS & Proportion & SS & Proportion \\
\hline \multicolumn{5}{|l|}{ NEE } \\
\hline Inter-annual & 206.54 & 0.029 & 148.14 & 0.070 \\
\hline Seasonal & 46.76 & 0.128 & 454.46 & 0.215 \\
\hline $\begin{array}{c}\text { Functional } \\
\text { change }\end{array}$ & 0 & 0.0 & 327.64 & 0.155 \\
\hline Error & 1364.30 & 0.843 & 1182.31 & 0.560 \\
\hline Total & 1617.60 & - & 2112.55 & - \\
\hline \multicolumn{5}{|l|}{$P_{\mathrm{D}}$} \\
\hline Inter-annual & 32.05 & 0.030 & 92.49 & 0.060 \\
\hline Seasonal & 292.07 & 0.275 & 633.77 & 0.412 \\
\hline $\begin{array}{c}\text { Functional } \\
\text { change }\end{array}$ & 113.36 & 0.107 & 198.78 & 0.129 \\
\hline Error & 623.85 & 0.588 & 614.56 & 0.399 \\
\hline Total & 1061.32 & - & 1539.60 & - \\
\hline \multicolumn{5}{|l|}{$R_{\mathrm{E}}$} \\
\hline Inter-annual & 3.83 & 0.028 & 9.99 & 0.043 \\
\hline Seasonal & 52.35 & 0.376 & 121.99 & 0.519 \\
\hline $\begin{array}{c}\text { Functional } \\
\text { change }\end{array}$ & 24.23 & 0.174 & 44.16 & 0.188 \\
\hline Error & 58.73 & 0.422 & 58.80 & 0.250 \\
\hline Total & 139.14 & - & 234.94 & - \\
\hline
\end{tabular}

The proportion of total variation in flux values attributed to each of the four components appears in the column labeled Proportion. $P<0.0001$ for each HOS model.

growing season (range of mean $\mathrm{ST}=14.1$ to $15.4^{\circ} \mathrm{C}$; Table 5). Slopes of $R_{\mathrm{E}}-\mathrm{ST}$ regressions were positive each year in each prairie (Table 4), indicating that $R_{\mathrm{E}}$ increased as ST increased each season. However, slopes of $R_{\mathrm{E}}-\mathrm{ST}$ regressions were much larger for the ungrazed prairie during the first 2 years of measurements. For a given increase in ST, then, the increase in $R_{\mathrm{E}}$ was considerably larger for the ungrazed than grazed prairie during these years.

\section{Daytime ecosystem $\mathrm{CO}_{2}$ exchange - seasonal and inter- annual variability}

Weekly means of $P_{\mathrm{D}}$ were linearly correlated $(P<0.05)$ with ST, Rn, deficit, and ppt5 on both grazed and ungrazed prairie. All correlations except those involving deficit were negative, meaning that $P_{\mathrm{D}}$ was stimu- lated by increases in temperature, $\mathrm{Rn}$, and rainfall and reduced by increases in deficit. Two variables, ST and $\mathrm{Rn}$, were retained in the stepwise multiple regression model with $P_{\mathrm{D}}$ for grazed prairie $\left[P_{\mathrm{D}}\left(\mathrm{mg} \mathrm{m}^{-2}\right.\right.$ $\left.\mathrm{s}^{-1}\right)=0.05347-0.00503 \times \mathrm{ST}-0.00029 \times \mathrm{Rn} ; \quad P<0.0001$, $\left.r^{2}=0.31, n=139\right]$. The final regression model for ungrazed prairie also included deficit $\left[P_{\mathrm{D}}\left(\mathrm{mg} \mathrm{m}^{-2} \mathrm{~s}^{-1}\right)\right.$ $=0.0616-0.00458 \times \mathrm{ST}-0.00046 \times \mathrm{Rn}+0.02345 \times$ deficit; $\left.P<0.0001, r^{2}=0.47, n=137\right]$. However, adding ST to a multiple regression model for ungrazed prairie that included $\mathrm{Rn}$ and deficit added little to the total SS explained by regression (Table 6).

For each prairie, the HOS analysis indicated that slopes of relationships between $P_{\mathrm{D}}$ and each variable retained in the multiple regression model varied significantly among years. A separate-slopes model accounted for $10.7 \%$ and $12.9 \%$ more variance in $P_{\mathrm{D}}$ in grazed and ungrazed prairies, respectively, than did the multiple regression model (Table 3 ). This contribution of functional change in explaining variance in $P_{\mathrm{D}}$ exceeded that of direct effects of inter-annual variation in environmental variables $(3.0 \%$ and $6.0 \%$ on grazed and ungrazed prairie) by greater than a factor of 2 . Permitting significant flux-climate relationships to vary among years improved regression estimates of $P_{\mathrm{D}}$ most during the 1998 season on grazed prairie and 1998 and 1999 seasons on ungrazed prairie (Fig. 2).

On both the prairies, variance in weekly means of $P_{\mathrm{D}}$ was better explained by seasonal than by direct effects of climate on fluxes or by changes in slopes of relationships between $P_{\mathrm{D}}$ and climatic variables (Table 3 ). For example, seasonal variation in climate explained more than twice the variance in $P_{\mathrm{D}}$ on grazed and ungrazed prairie as the total of IAV in climatic factors (sum of direct effects of inter-annual variation and functional change). The variance in $P_{\mathrm{D}}$ accounted for by regression models was smaller for grazed than ungrazed prairie.

For the grazed prairie, slopes of $P_{\mathrm{D}}-\mathrm{ST}$ and $P_{\mathrm{D}}-\mathrm{Rn}$ relationships for each growing season (Table 4) were highly correlated with mean ST during the growing season (Table 5). Slopes of $P_{\mathrm{D}}-\mathrm{ST}$ regressions became less negative as mean ST increased. Thus, increasing weekly means of ST within a season increased $P_{\mathrm{D}}$ more during the years in which ST was relatively low than high. Conversely, increasing weekly means of Rn increased $P_{\mathrm{D}}$ more during years in which the seasonal average of ST was high than low. For ungrazed prairie, by contrast, slopes of $P_{\mathrm{D}}-\mathrm{ST}, P_{\mathrm{D}}-\mathrm{Rn}$, and $P_{\mathrm{D}}$-deficit regressions for the five growing seasons depended more on precipitation summed from the end of the previous growing season to the beginning of the current season than on seasonal means of ST (Table 5). Importantly, slopes of $P_{\mathrm{D}}-\mathrm{ST}$ regressions calculated for each growing season changed from positive to negative 
Table 4 Slopes of selected $\mathrm{CO}_{2}$ flux-climate relationships calculated each growing season for grazed and ungrazed mixed-grass prairie using weekly data

\begin{tabular}{|c|c|c|c|c|c|c|}
\hline \multirow[b]{2}{*}{ Year } & \multicolumn{2}{|c|}{$\begin{array}{l}R_{\mathrm{E}}-\mathrm{ST} \text { slope } \\
\left(\mathrm{mg} \mathrm{m}^{-2} \mathrm{~s}^{-1}{ }^{\circ} \mathrm{C}^{-1}\right)\end{array}$} & \multicolumn{2}{|c|}{$\begin{array}{l}P_{\mathrm{D}}-\mathrm{ST} \text { slope } \\
\left(\mathrm{mg} \mathrm{m}^{-2} \mathrm{~s}^{-1}{ }^{\circ} \mathrm{C}^{-1}\right)\end{array}$} & \multicolumn{2}{|c|}{$\begin{array}{l}P_{\mathrm{D}}-\mathrm{Rn} \text { slope } \\
\left(\mathrm{mg} \mathrm{m}^{-2} \mathrm{~s}^{-1} \mathrm{~W}^{-1} \mathrm{~m}^{-2}\right)\end{array}$} \\
\hline & Grazed & Ungrazed & Grazed & Ungrazed & Grazed & Ungrazed \\
\hline 1997 & $4.10 \times 10^{-3}$ & $7.44 \times 10^{-3}$ & $-5.36 \times 10^{-3}$ & $-15.55 \times 10^{-3}$ & $-2.51 \times 10^{-4}$ & $-9.56 \times 10^{-5}$ \\
\hline 1998 & $3.33 \times 10^{-3}$ & $5.26 \times 10^{-3}$ & $5.06 \times 10^{-3}$ & $10.18 \times 10^{-3}$ & $-7.67 \times 10^{-4}$ & $-1.29 \times 10^{-3}$ \\
\hline 1999 & $5.56 \times 10^{-3}$ & $5.50 \times 10^{-3}$ & $-1.89 \times 10^{-3}$ & $3.60 \times 10^{-3}$ & $-4.82 \times 10^{-4}$ & $-9.64 \times 10^{-4}$ \\
\hline 2000 & $3.79 \times 10^{-3}$ & $3.62 \times 10^{-3}$ & $-9.69 \times 10^{-3}$ & $-6.59 \times 10^{-3}$ & $-9.79 \times 10^{-5}$ & $-3.16 \times 10^{-4}$ \\
\hline 2001 & $3.12 \times 10^{-3}$ & $3.74 \times 10^{-3}$ & $-13.11 \times 10^{-3}$ & $-9.29 \times 10^{-3}$ & $9.81 \times 10^{-5}$ & $-2.20 \times 10^{-4}$ \\
\hline
\end{tabular}

Fluxes include rates of night-time respiration $\left(R_{\mathrm{E}} ; \mathrm{mg} \mathrm{m}^{-2} \mathrm{~s}^{-1}\right)$ and daytime ecosystem $\mathrm{CO}_{2}$ exchange $\left(P_{\mathrm{D}} ; \mathrm{mg} \mathrm{m}^{-2} \mathrm{~s}^{-1}\right)$. Climatic variables include soil temperature $\left(\mathrm{ST} ;{ }^{\circ} \mathrm{C}\right)$ and net radiation $\left(\mathrm{Rn} ; \mathrm{W} \mathrm{m}^{-2}\right)$.

when precipitation before the growing season exceeded about $90 \mathrm{~mm}$. That is, an increase in the weekly average of ST increased net $\mathrm{CO}_{2}$ loss during daylight from ungrazed prairie when precipitation before the growing season was low, but increased net $\mathrm{CO}_{2}$ uptake during daylight during years when precipitation was high. Because the sign of $P_{\mathrm{D}}-\mathrm{ST}$ slopes in the HOS model differed among years, the relationship between $P_{\mathrm{D}}$ and values of ST corrected for collinearity with $\mathrm{Rn}$ and deficit was weak when assessed across the 5 years of data combined (Table 6). Slopes of $P_{D}-R n$ regressions from HOS models were more negative on the ungrazed than grazed prairie in four of the 5 years (Table 4).

Slopes of flux-climate relationships vary among years when climate anomalies alter ecological processes that regulate the response of fluxes to short-term change in the environment. Canopy development is among the processes that may be altered by climatic anomalies. Effects of precipitation before the growing season on slopes of $P_{\mathrm{D}}$-climate regressions for ungrazed prairie apparently were mediated partly by year-to-year differences in dynamics of LAI. The greater was the precipitation before the season, the later in the season LAI peaked [day of year of peak LAI $=126.67+17.35 \times$ sum of precipitation before season $(\mathrm{mm}) ; P=0.09, r^{2}=0.75$, $n=4)$. For ungrazed prairie, slopes of $P_{\mathrm{D}}-\mathrm{ST}, P_{\mathrm{D}}-\mathrm{Rn}$, and $P_{\mathrm{D}}$-deficit regressions for the 4 growing seasons during which LAI was measured (1997-2000) were linearly correlated with the day of the year on which maximum LAI occurred (Table 5). An increase in the weekly average of ST increased $P_{\mathrm{D}}$ on ungrazed prairie more when LAI peaked late than early in the season. Conversely, $P_{\mathrm{D}}$ increased more per unit of increase in Rn during the years when LAI peaked early than late in the season. Inter-annual variation in slopes of $P_{\mathrm{D}^{-}}$climate relationships was not correlated with either the maximum LAI measured each season or the mean LAI for each growing season for ungrazed prairie or with any the three indices of LAI we calculated for grazed prairie.

\section{Net ecosystem exchange of $\mathrm{CO}_{2}-$ seasonal and inter- annual variability}

Weekly means of NEE were significantly linearly correlated with means of ST, Rn, and ppt5 on ungrazed prairie $(P<0.0001, n=139)$ and with means of ST $(P=0.0003)$ and $\mathrm{Rn}(P<0.0001)$ on grazed prairie $(n=140)$. All correlations were negative, meaning that NEE was stimulated by increases in weekly values of temperature, $\mathrm{Rn}$, and rainfall. Three variables, ST, $\mathrm{Rn}$, and ppt5, were retained in the multiple regression model for NEE for ungrazed prairie [NEE $\left(\mathrm{g} \mathrm{m}^{-2}\right.$ day $\left.^{-1}\right)=5.4243-0.0399 \times$ ST $-0.0199 \times \mathrm{Rn}-0.0612 \times$ ppt5; $\left.P<0.0001, r^{2}=0.29, n=139\right]$. The final regression model for grazed prairie included $\mathrm{Rn}$ only [NEE $\left(\mathrm{g} \mathrm{m}^{-2}\right.$ day $\left.^{-1}\right)=2.7235-0.0162 \times \mathrm{Rn} ; P<0.00013, r^{2}=0.16$, $n=140]$.

The HOS analysis indicated that effects of ST and Rn on NEE of ungrazed prairie varied among years, whereas the effect of ppt5 on NEE did not change among years. A separate-slopes model accounted for $15.5 \%$ more variance in NEE than did the single-slopes model for ungrazed prairie (functional change; Table 3) and appeared to improve regression estimates of NEE most during the 1998 and 1999 seasons (Fig. 3). For grazed prairie, by contrast, variation in weekly means of NEE was adequately described by a single-slopes model with Rn. Because slopes of NEE-Rn relationships did not differ significantly among years for grazed prairie $(P=0.49)$, functional change was not detected.

For ungrazed prairie, slopes of NEE-ST and NEE-Rn regressions for the five growing seasons of measurements were correlated with interannual variation in the amount of precipitation that fell before the growing season and, for the 4 years during which LAI was 
Table 5 Results of regression analyses relating slopes of $\mathrm{CO}_{2}$ flux-climate relationships calculated for each of the five growing seasons using weekly data (dependent variable) to means of climatic variables for each season or to the day of the year on which LAI peaked each season (independent variables)

\begin{tabular}{|c|c|c|c|c|c|}
\hline Prairie, dependent variable (slope) & Independent variable & Intercept & Slope & $r^{2}$ & $P$-value \\
\hline \multicolumn{6}{|l|}{ Grazed } \\
\hline$R_{\mathrm{E}}-\mathrm{ST}$ & ST (previous season) & -0.0235 & $1.9 \times 10^{-3}$ & 0.88 & 0.04 \\
\hline$P_{\mathrm{D}^{-}}-\mathrm{ST}$ & ST & -0.1746 & 0.0106 & 0.84 & 0.02 \\
\hline$P_{\mathrm{D}^{-}}-\mathrm{Rn}$ & ST & 0.0076 & $-4.9 \times 10^{-4}$ & 0.77 & 0.03 \\
\hline \multicolumn{6}{|l|}{ Ungrazed } \\
\hline$P_{\mathrm{D}^{-S T}}$ & \multirow{5}{*}{$\begin{array}{l}\text { Precipitation before } \\
\text { season }\end{array}$} & 0.0284 & $-3.2 \times 10^{-4}$ & 0.91 & 0.007 \\
\hline$P_{\mathrm{D}}-\mathrm{Rn}$ & & -0.0023 & $1.7 \times 10^{-5}$ & 0.87 & 0.01 \\
\hline$P_{\mathrm{D}}$-deficit & & 0.0974 & $6.8 \times 10^{-4}$ & 0.82 & 0.02 \\
\hline NEE-ST & & 1.2247 & -0.0122 & 0.76 & 0.03 \\
\hline NEE-Rn & & -0.0809 & $5.9 \times 10^{-4}$ & 0.74 & 0.04 \\
\hline \multicolumn{6}{|l|}{ Ungrazed } \\
\hline$P_{\mathrm{D}^{-S T}}$ & \multirow{5}{*}{$\begin{array}{l}\text { Day of peak } \\
\text { LAI }\end{array}$} & 0.0752 & $-3.9 \times 10^{-4}$ & 0.92 & 0.03 \\
\hline$P_{\mathrm{D}}-\mathrm{Rn}$ & & -0.0049 & $2.2 \times 10^{-5}$ & 0.93 & 0.02 \\
\hline$P_{\mathrm{D}^{-}}$-deficit & & 0.1876 & $-7.8 \times 10^{-4}$ & 0.78 & 0.08 \\
\hline NEE-ST & & 3.1854 & -0.0158 & 0.91 & 0.03 \\
\hline NEE-Rn & & -0.1803 & $8.0 \times 10^{-4}$ & 0.92 & 0.03 \\
\hline
\end{tabular}

Data for LAI are available for four seasons only. Fluxes include net ecosystem exchange of $\mathrm{CO}_{2}\left(\mathrm{NEE} ; \mathrm{g} \mathrm{m}^{-2} \mathrm{day}^{-1}\right)$, rate of daytime ecosystem $\mathrm{CO}_{2}$ exchange $\left(P_{\mathrm{D}} ; \mathrm{mg} \mathrm{m}^{-2} \mathrm{~s}^{-1}\right)$, and night-time respiration rate $\left(R_{\mathrm{E}} ; \mathrm{mg} \mathrm{m}^{-2} \mathrm{~s}^{-1}\right)$. Climatic variables include soil temperature $\left(\mathrm{ST} ;{ }^{\circ} \mathrm{C}\right)$, net radiation $\left(\mathrm{Rn} ; \mathrm{W} \mathrm{m}^{-2}\right)$, deficit $\left(\mathrm{mm} \mathrm{day}^{-1}\right)$, and precipitation summed from the end of the previous growing season to the beginning of the current season (precipitation before season; $\mathrm{mm}$ ).

measured, with the day of the year on which maximum LAI occurred (Table 5). Slopes of NEE-ST regressions were positive when precipitation was $<90 \mathrm{~mm}$, meaning that increasing weekly means of ST within a season increased net $\mathrm{CO}_{2}$ loss during the years with low precipitation. By contrast, NEE increased as weekly values of ST increased during the years when precipitation was $>90 \mathrm{~mm}$. Increasing weekly means of ST within a season increased NEE more when LAI peaked late than early in the season (Table 5). Because the sign of NEE-ST slopes differed among the years, the relationship between NEE and values of ST was weak when assessed across the 5 years of data combined (Table 6).

Direct effects of inter-annual variation in measured climatic variables explained little variance in NEE for either prairie (2.9\% and $7.0 \%$ for grazed and ungrazed prairie, respectively; Table 3). Seasonal climatic variation accounted for slightly more variance than did either direct effects of the environment or functional change, but much of variance in NEE was not explained by measured variables. Indeed, $84.3 \%$ of variance in NEE on grazed prairie was attributed to random error.

\section{Relationships between seasonal means of fluxes and climate}

Seasonal means of $P_{\mathrm{D}}$ correlated more highly with mean ST than with means of other climatic variables for both grazed $\left(r^{2}=0.63, P=0.07\right)$ and ungrazed prairie, $\left(r^{2}=0.44, P=0.14\right)$, although neither relationship was significant. For grazed prairie, $P_{\mathrm{D}}$ declined linearly as mean ST increased $\left[P_{\mathrm{D}} \quad\left(\mathrm{mg} \mathrm{m}^{-2} \mathrm{~s}^{-1}\right)=-0.4151+\right.$ $0.0188 \times \mathrm{ST}]$. For ungrazed prairie, the $P_{\mathrm{D}}-\mathrm{ST}$ relationship was best fit with a hyperbolic function in which net $\mathrm{CO}_{2}$ uptake declined as the seasonal mean of ST increased $\left[P_{\mathrm{D}}\left(\mathrm{mg} \mathrm{m}^{-2} \mathrm{~s}^{-1}\right)=((-0.0186 \times \mathrm{ST}) /\right.$ $(-12.756+\mathrm{ST}))]$.

Variation in seasonal means of NEE for grazed and ungrazed prairies also correlated more highly with variation in ST than with other climatic variables or with precipitation measured before or during the growing season. Relationships between seasonal means of NEE and ST for both grazed and ungrazed prairies were best fit with a hyperbolic function in which net $\mathrm{CO}_{2}$ uptake decreased (NEE became less negative) as temperature increased (Fig. 4).

\section{Discussion}

\section{Functional change}

The two components in our regression model that together accounted for IAV in $\mathrm{CO}_{2}$ fluxes, functional change and direct effects of climatic variation, accounted for about $20 \%$ of variance in weekly means of NEE, $P_{\mathrm{D}}$, and $R_{\mathrm{E}}$ on northern mixed-grass prairie. 
Table 6 ANOVA results for multiple regression models for NEE and daytime $\left(P_{\mathrm{D}}\right)$ and night-time $\mathrm{CO}_{2}$ exchange rates $\left(R_{\mathrm{E}}\right)$ on grazed and ungrazed mixed-grass prairie

\begin{tabular}{lcccrcr}
\hline & \multicolumn{2}{c}{ Grazed } & & \multicolumn{2}{c}{ Ungrazed } \\
\cline { 2 - 3 } \cline { 5 - 6 } Independent variable & MS & F & & MS & \multicolumn{2}{c}{$\mathrm{F}$} \\
\hline NEE & & & & & \\
Rn & 253.3 & $25.6^{* * *}$ & & 214.0 & $19.1^{* * *}$ \\
ST & - & - & & 3.0 & 0.3 \\
ppt5 & - & - & & 38.1 & 3.4 \\
Error & 9.9 & - & & 11.2 & - \\
$P_{\mathrm{D}}$ & & & & \\
Rn & 44.8 & $8.3^{*}$ & & 124.4 & $20.6^{* * *}$ \\
ST & 53.6 & $10.0^{*}$ & & 33.2 & $5.5^{+}$ \\
Deficit & - & - & & 64.0 & $10.6^{* *}$ \\
Error & 5.4 & - & & 6.0 & - \\
$R_{\mathrm{E}}$ & & & & & \\
ST & 56.2 & $92.8^{* * *}$ & & 40.1 & $51.8^{* * *}$ \\
$P_{\mathrm{D}}$ & - & - & & 3.2 & $4.2^{+}$ \\
Deficit & - & - & & 5.0 & $6.5^{*}$ \\
Error & 0.6 & - & & 0.8 & - \\
\hline
\end{tabular}

Mean squares (MS) were calculated using Type III sum of squares (SS), the additional SS resulting from including each independent variable in the regression model given the effect of other variables in the model. Independent climatic variables include soil temperature (ST), net radiation ( $\mathrm{Rn})$, deficit, and the 5-week moving average of precipitation (ppt5).

*** $P<0.0001$.

${ }^{* *} P<0.001$.

${ }^{*} P<0.01$.

${ }^{+} P<0.05$.

Functional change explained more than twice the variance in fluxes of direct effects of climatic variability. Grazing did not consistently influence the contribution of functional change to flux variability (contrary to our hypothesis). But, grazing altered which climatic variable was most highly correlated with year-to-year differences in slopes of flux-climate relationships, reduced IAV in growing season means of fluxes, lessened the strength of flux-climate correlations, and increased $\mathrm{NEE}$, apparently by reducing $R_{\mathrm{E}}$ relatively more than $P_{\mathrm{D}}$. Most of these trends, including reduced variability in fluxes, reduced $R_{\mathrm{E}}$, and the weakening of fluxclimate correlations, are consistent with the view that grazing lessened the potential impact of plants on ecosystem fluxes. Because relationships between weekly values of fluxes and climatic regulators on mixed-grass prairie change annually, year-to-year differences in the $C$ balance of these ecosystems cannot readily be predicted from knowledge of IAV in climatic conditions alone.

Most of the IAV in NEE, $P_{\mathrm{D}}$, and $R_{\mathrm{E}}$ on mixed-grass prairies was attributable to functional change. Hui et al.

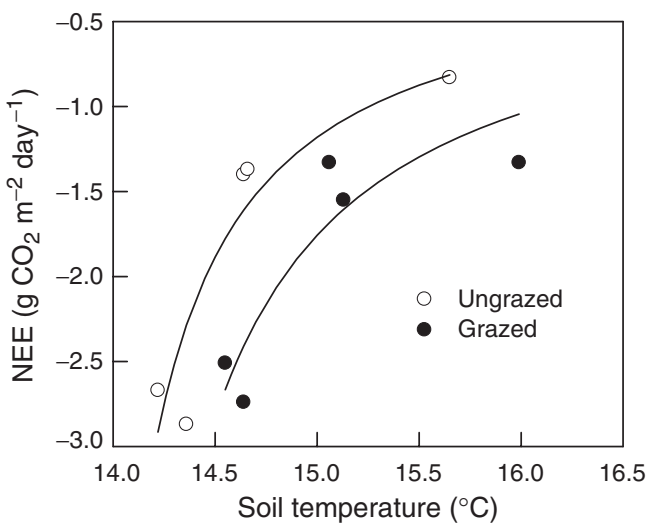

Fig. 4 Relationship between growing season means of daily values of NEE $\left(\mathrm{g} \mathrm{CO}_{2} \mathrm{~m}^{-2} \mathrm{day}^{-1}\right)$ and soil temperature $\left({ }^{\circ} \mathrm{C}\right)$ for grazed and ungrazed mixed-grass prairie. Lines are hyperbolic functions $[y=((a \times x) /(b+x))]$ fit to NEE-temperature relationships for grazed $\left(a=-0.15, b=-13.75 ; r^{2}=0.75, P=0.04\right)$ and ungrazed prairie $\left(a=-0.10, b=-13.73 ; r^{2}=0.80, P=0.03\right)$.

(2003) also found that functional change generally accounted for slightly more of IAV in forest fluxes than did direct effects of IAV in climate. Functional change explained $13.1 \%$ of variance in $R_{\mathrm{E}}$ and $10 \%$ of variance in NEE for loblolly pine ( $P$. taeda L.) forest in North Carolina, USA (Hui et al., 2003), values similar to the contributions of about $18 \%\left(R_{\mathrm{E}}\right)$ and $15.5 \%(\mathrm{NEE})$ we observed for grazed and ungrazed prairies combined and the ungrazed prairie, respectively.

Functional change results from inter-annual change in the responsiveness of fluxes to climatic variables. That relationships between $\mathrm{C}$ fluxes and climatic factors vary through time is well established. It is known, for example, that the responsiveness of $P_{\mathrm{D}}$ to light or $\mathrm{Rn}$ depends on soil water content and LAI (Polley et al., 2007), which may depend, in turn, on temperature. Similarly, the responsiveness of $R_{\mathrm{E}}$ to temperature variation may depend on the availability of C substrates and on soil water content (Mielnick \& Dugas, 2000; Harper et al., 2005; Polley et al., 2006). IAV in NEE and other $\mathrm{CO}_{2}$ fluxes has been documented for grasslands (Flanagan et al., 2002; Frank, 2002; Suyker et al., 2003; Owensby et al., 2006) and other ecosystems (Barford et al., 2001), but the relative contributions of direct and indirect effects of climatic variability to IAV in fluxes are not well established. If variability in $\mathrm{CO}_{2}$ fluxes results largely from direct effects of seasonal and inter-annual climatic variability, flux-climate relationships derived from short-term measurements might be used to predict $C$ balance. If climate effects differ significantly among years, as here, more detailed or sophisticated models will be required for prediction. 


\section{Variability in flux-climate relationships}

Interannual variation in regression slopes of $P_{\mathrm{D}}$ and NEE vs. climatic variables was regulated by different factors on grazed and ungrazed prairie. IAV in slopes of relationships between weekly means of $P_{\mathrm{D}}$ and both ST and $\mathrm{Rn}$ correlated with the growing season average of ST on grazed prairie but with precipitation prior to the growing season on ungrazed prairie. Similarly, IAV in slopes of NEE-ST and NEE-Rn relationships on ungrazed prairie correlated more highly with precipitation before the season than with mean ST.

Variability in precipitation thus appears ultimately to explain functional change on ungrazed prairie. Effects of precipitation, in turn, were expressed partly through inter-annual differences in dynamics of LAI. The greater was the precipitation before the season, the later in the season LAI peaked. The later in the season LAI peaked, the more net $\mathrm{CO}_{2}$ uptake increased per unit of increase in ST. Surprisingly, neither peak values of LAI nor mean LAI for the season contributed to functional change on ungrazed prairie. Ecological processes on grasslands are strongly influenced by variability in precipitation (Knapp \& Smith, 2001; Knapp et al., 2002). Precipitation regulates biomass production on northern mixed-grass prairie (Smart et al., 2007), and as demonstrated here, the timing and duration of canopy development. Fluxes, in turn, are highly responsive to biomass and LAI (Flanagan et al., 2002). Frank (2002), for example, found that peak levels of NEE coincided with peaks in LAI and biomass on mixed-grass prairie.

Soil temperature, rather than precipitation, explained IAV in slopes of flux-climate regressions on grazed prairie. Temperature affects several ecological processes that potentially regulate $\mathrm{CO}_{2}$ fluxes and the response of fluxes to short-term change in climate. These processes include canopy development (Wan et al., 2005), transpiration rates (Polley et al., 2008), and soil water content (Zhou et al., 2007). Effects of greater ST on the response of $\mathrm{CO}_{2}$ uptake to $\mathrm{Rn}$ and other climatic factors may be positive, especially early in the growing season. Increasing ST increased aboveground biomass and, by inference, $P_{\mathrm{D}}$ on tallgrass prairie during spring (Wan et al., 2005), for example. Effects of greater ST on the response of NEE to within season change in climate also may be negative, as indicated by our data. Aboveground biomass during summer declined as ST increased on tallgrass prairie (Wan et al., 2005), perhaps because higher ST reduced photosynthesis by increasing ET and reducing soil water content.

The climatic parameter that best explained variability in growing season means of fluxes was not necessarily the variable that best explained the year-to-year differences in slopes of flux-climate regressions that largely accounted for IAV in fluxes. For ungrazed prairie, for example, slopes of regressions relating weekly averages of NEE and $P_{\mathrm{D}}$ with climatic variables within each growing season depended on variability in precipitation, whereas differences in annual means of NEE and $P_{\mathrm{D}}$ were best explained by variation in growing season ST. Correlations derived using annual means of fluxes and climatic variables may not reveal underlying causes of flux variability.

\section{Influence of grazing on seasonal means of fluxes}

Grazing increased growing season means of NEE by reducing $R_{\mathrm{E}}$ relatively more than $P_{\mathrm{D}}$, and reduced IAV in means of $\mathrm{CO}_{2}$ fluxes. Peak LAI was greater on moderately grazed than ungrazed prairie possibly because grazing stimulated aboveground production, but grazers likely affected fluxes either directly or indirectly by removing or trampling plant material. Grassland respiration is directly dependent on the availability of recently fixed $\mathrm{C}$ substrates and possibly on the form in which substrates are available (Craine et al., 1999; Polley et al., 2006). Heavy grazing has been found to reduce root biomass on northern mixed-grass prairie even when aboveground productivity is not affected (Biondini et al., 1998), suggesting grazing reduced $R_{\mathrm{E}}$ and the responsiveness of $R_{\mathrm{E}}$ to weekly change in ST partly by reducing the input of labile $\mathrm{C}$ to soil and thereby reducing microbial respiration. In multiple regressions, $R_{\mathrm{E}}$ depended on net $\mathrm{CO}_{2}$ uptake during the preceding daylight period $\left(P_{\mathrm{D}}\right)$ only on ungrazed prairie, further evidence that grazing partially decoupled $R_{\mathrm{E}}$ from short-term shifts in $\mathrm{CO}_{2}$ uptake. Slopes of $P_{\mathrm{D}}-\mathrm{Rn}$ relationships were less negative on grazed than ungrazed grassland in 4 or 5 years, meaning that grazing generally reduced the responsiveness of $P_{\mathrm{D}}$ to Rn. Grazers also indirectly affected fluxes by increasing ST. Growing season averages of daytime and daily ( $24 \mathrm{~h}$ ) ST were greater on grazed than ungrazed prairie by 0.91 and $0.37^{\circ} \mathrm{C}$, respectively, during the 5 years of measurements, possibly because grazing reduced biomass of dead plant material. The accumulation of dead material on the soil surface and within plant canopies reduces the amount of solar radiation that reaches the soil, resulting in cooler soil (Knapp \& Seastedt, 1986). Grazing has been shown to reduce standing dead biomass and litter mass on northern mixed-grass prairie (Biondini et al., 1998). Partly because daytime ST was greatest at the grazed site, seasonal means of $P_{\mathrm{D}}$ usually were smaller on grazed than ungrazed prairie.

\section{Conclusions}

Our results and those from similar analyses (Hui et al., 2003; Richardson et al., 2007) indicate that predictive 
models must accommodate change in biotic response functions to accurately simulate the annual dynamics of $\mathrm{CO}_{2}$ fluxes. Even moderate grazing may further complicate prediction by changing the identity of the primary climatic driver of year-to-year change in the sensitivity of fluxes to environmental forcings. Results also indicate that a relatively small increase in ST, as may occur as a result of global warming, or change in the responsiveness of $R_{\mathrm{E}}$ to $\mathrm{ST}$, as occurred with grazing in this study, may significantly influence $\mathrm{C}$ exchange on northern mixed-grass prairie.

\section{Acknowledgements}

Katherine Jones and Patricia Mielnick participated in data analysis. Dafeng Hui, Phillip Sims, and Tony Svejcar provided helpful reviews.

\section{References}

Angell R, Svejcar T, Bates J, Saliendra NZ, Johnson DA (2001) Bowen ratio and closed chamber carbon dioxide flux measurements over sagebrush steppe vegetation. Agricultural and Forest Meteorology, 108, 153-161.

Barford CC, Wofsy SC, Goulden ML et al. (2001) Factors controlling long- and short-term sequestration of atmospheric $\mathrm{CO}_{2}$ in a mid-latitude forest. Science, 294, 1688-1691.

Biondini ME, Patton BD, Nyren PE (1998) Grazing intensity and ecosystem processes in a northern mixed-grass prairie, USA. Ecological Applications, 8, 469-479.

Craine JM, Wedin DA, Chapin FA III (1999) Predominance of ecophysiological controls on soil $\mathrm{CO}_{2}$ flux in a Minnesota grassland. Plant and Soil, 207, 77-86.

Dugas WA (1993) Micrometeorological and chamber measurements of $\mathrm{CO}_{2}$ flux from bare soil. Agricultural and Forest Meteorology, 67, 115-128.

Dugas WA, Evans R, Hollinger D (2001) Eddy Correlation and Bowen Ratio/Energy Balance Measurements of Sensible Heat, Latent Heat, and $\mathrm{CO}_{2}$ Flux over a Tallgrass Prairie. BRC Report \# 01-3. Blackland Research Center, Temple, TX.

Dugas WA, Heuer ML, Mayeux HS (1999) Carbon dioxide fluxes over bermuda grass, native prairie, and sorghum. Agricultural and Forest Meteorology, 93, 121-139.

Flanagan LB, Wever LA, Carlson PJ (2002) Seasonal and interannual variation in carbon dioxide exchange and carbon balance in a northern temperate grassland. Global Change Biology, 8, 599-615.

Frank AB (2002) Carbon dioxide fluxes over a grazed prairie and seeded pasture in the Northern Great Plains. Environmental Pollution, 116, 397-403.

Frank AB, Dugas WA (2001) Carbon dioxide fluxes over a northern semiarid, mixed-grass prairie. Agricultural and Forest Meteorology, 108, 317-326.

Frank AB, Sims PL, Bradford JA, Mielnick PC, Dugas WA, Mayeux HS (2000) Carbon dioxide fluxes over three Great Plains Grasslands. In: The Potential of US Grazing Lands to
Sequester Carbon and Mitigate the Greenhouse Effect (eds Follett RF, Kimble JM, Lal R), pp. 167-188. CRC Press, Boca Raton, FL, USA.

Harper CW, Blair JM, Fay PA, Knapp AK, Carlisle JD (2005) Increased rainfall variability and reduced rainfall amount decreases soil $\mathrm{CO}_{2}$ flux in a grassland ecosystem. Global Change Biology, 11, 322-334.

Hui D, Luo Y, Katul G (2003) Parititioning interannual variability in net ecosystem exchange between climatic variability and functional change. Tree Physiology, 23, 433-442.

Knapp AK, Fay PA, Blair JM et al. (2002) Rainfall variability, carbon cycling, and plant species diversity in mesic grassland. Science, 298, 2202-2205.

Knapp AK, Seastedt TR (1986) Detritus accumulation limits productivity of tallgrass prairie. BioScience, 36, 662-668.

Knapp AK, Smith MD (2001) Variation among biomes in temporal dynamics of aboveground primary production. Science, 291, 481-484.

Mielnick PC, Dugas WA (2000) Soil $\mathrm{CO}_{2}$ flux in a tall-grass prairie. Soil Biology and Biochemistry, 32, 221-228.

Owensby CE, Ham JM, Auen LM (2006) Fluxes of $\mathrm{CO}_{2}$ from grazed and ungrazed tallgrass prairie. Rangeland Ecology and Management, 59, 111-127.

Polley HW, Dugas WA, Mielnick PC, Johnson HB (2007) $\mathrm{C}_{3}-\mathrm{C}_{4}$ composition and prior carbon dioxide treatment regulate the response of grassland carbon and water fluxes to carbon dioxide. Functional Ecology, 21, 11-18.

Polley HW, Johnson HB, Fay PA, Sanabria J (2008) Initial response of evapotranspiration from tallgrass prairie vegetation to $\mathrm{CO}_{2}$ at subambient to elevated concentrations. Functional Ecology, 22, 163-174.

Polley HW, Mielnick PC, Dugas WA, Johnson HB, Sanabria J (2006) Increasing $\mathrm{CO}_{2}$ from subambient to elevated concentrations increases grassland respiration per unit of net carbon fixation. Global Change Biology, 12, 1390-1399.

Richardson AD, Hollinger DY, Aber JD, Ollinger SV, Braswell BH (2007) Environmental variation is directly responsible for short- but not long-term variation in forestatmosphere carbon exchange. Global Change Biology, 13, 788-803.

Saleska SR, Miller SD, Matross DM et al. (2003) Carbon in Amazon forests: unexpected seasonal fluxes and disturbance-induced losses. Science, 302, 1554-1557.

Sims PL, Bradford JA (2001) Carbon dioxide fluxes in a Southern Plains prairie. Agricultural and Forest Meteorology, 109, 117-134.

Smart AJ, Dunn BH, Johnson PS, Xu L, Gates RN (2007) Using weather data to explain herbage yield on three Great Plains plant communities. Rangeland Ecology and Management, 60, 146-153.

Soussana JF, Allard V, Pilegaard Ket al. (2007) Full accounting of the greenhouse gas $\left(\mathrm{CO}_{2}, \mathrm{~N}_{2} \mathrm{O}, \mathrm{CH}_{4}\right)$ budget of nine European grassland sites. Agriculture, Ecosystems \& Environment, 121, 121-134.

Suyker AE, Verma SB, Burba GG (2003) Interannual variability in net $\mathrm{CO}_{2}$ exchange of a native tallgrass prairie. Global Change Biology, 9, 255-265. 
Stephenson NL (1990) Climatic control of vegetation distribution: the role of the water balance. American Naturalist, 135, 649-670.

Tian H, Melillo JM, Kicklighter DW, McGuire AD, Helfrich JVK III, Moore B III, Vörösmarty CJ (1998) Effect of interannual climate variability on carbon storage in Amazonian ecosystems. Nature, 396, 664-667.

Wan S, Hui D, Wallace LL (2005) Direct and indirect warming effects on ecosystem carbon processes in a tallgrass prairie. Global Biogeochemical Cycles, 19, GB2014, doi: 10.1029/ $2004 \mathrm{~GB} 002315$.
Webb EK, Pearman GI, Leuning R (1980) Correction of flux measurements for density effects due to heat and water vapor transfer. Quarterly Journal of the Royal Meteorological Society, 106, 85-100.

Xu L, Baldocchi DD (2004) Seasonal variation in carbon dioxide exchange over a Mediterranean annual grassland in California. Agricultural and Forest Meteorology, 123, 79-96.

Zhou X, Wan S, Luo Y (2007) Source components and interannual variability in soil $\mathrm{CO}_{2}$ efflux under experimental warming and clipping in a grassland ecosystem. Global Change Biology, 13, 761-775. 